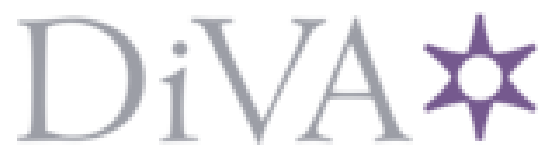

http://www.diva-portal.org

\title{
Postprint
}

This is the accepted version of a paper published in Urban Forestry \& Urban Greening. This paper has been peer-reviewed but does not include the final publisher proof-corrections or journal pagination.

Citation for the original published paper (version of record):

Askerlund, P., Almers, E. (2016)

Forest gardens - new opportunities for urban children to understand and develop relationships with other organisms.

Urban Forestry \& Urban Greening, 20: 187-197

http://dx.doi.org/10.1016/j.ufug.2016.08.007

Access to the published version may require subscription.

N.B. When citing this work, cite the original published paper.

Permanent link to this version:

http://urn.kb.se/resolve?urn=urn:nbn:se:hj:diva-31546 
Forest gardens - new opportunities for urban children to understand and develop relationships with other organisms

Per Askerlund ${ }^{a}$ (corresponding author; per.askerlund@ju.se)

Ellen Almers ${ }^{\mathrm{b}}$ (ellen.almers@ju.se)

a,bJönköping University, School of Education and Communication

Box 1026, SE-551 11 Jönköping, Sweden 


\section{Forest gardens - new opportunities for urban children to understand 2 and develop relationships with other organisms}

\section{Abstract}

This case study explores a learning situation in a forest garden in Sweden. A forest garden is an edible polyculture landscape with different layers of mostly perennial vegetation. The forest garden is designed to maximize the yield of useful plants while minimizing the input of energy and resources, including human labour. Forest gardens may offer learning situations that contextualize interconnectedness and relations between organisms as well as situations that are beneficial for evaluative development (Kellert, 2002), i.e. the development of values, beliefs and moral perspectives in children.

Twenty-seven seven to eight year old primary school children were followed in the first six months of a three year project in which they participated in developing a forest garden. The aim of the study is to investigate how the children reason with respect to different organisms' dependence on and relations to each other, themselves included. Specifically:

How do the children describe their own relationships with other organisms, as well as the relationships between other organisms in the forest garden?

What values of nature are expressed by the children, and in relation to which situations in the forest garden?

Data were collected in the form of field notes, audio and video recordings and photos from the children's visits to the forest garden. The photos were used for stimulated recall in focus group interviews. The data were analysed using a combination of qualitative content analysis (Patton, 2002) and semi-quantitative methods.

The children in the study presented a unidirectional perspective about the relationship between themselves and the organisms, especially the insects, in the forest garden. Rather than asking what these organisms can do for me/us, they pose the question: What can I/we do for the bugs/plants/ bees?

The humanistic values, expressed by the children as a willingness to help other organisms (mostly insects) are in line with the explicit aims of the former curriculum for Biology to "promote care and respect for nature". We should note that these humanistic values are no longer explicitly stated in the current curriculum. It is striking that the anthropocentric ecosystem services perspective (introduced in the current curriculum from grade 4), is so rare in the data. The children seldom mentioned the benefits for humans from insect pollination, even though this relationship is clearly stated by the pedagogues together with humanistic values.

In observations, the children showed a great deal of curiosity for the natural environment (naturalistic value) as well as joy and enthusiasm about participating in the different activities that took place in the forest garden. Aesthetic values were expressed in relation to flowers, cones, berries, a snail's shell etc. 
This study shows that forest gardens have the potential to be places where children can connect emotionally and cognitively to other organisms.

\section{Introduction}

Forest gardens have been established in both urban and rural areas in the temperate world in recent years. Inspired by tropical agroforestry practices, these forest gardens are designed to resemble multi-layered forest edges. The design and orientation aims to maximize the inflow of solar energy to the vegetation in order to enhance photosynthesis, producing as many edible and functional plants as possible (Whitefeld, 2002; Jacke and Toensmeier, 2005; Crawford, 2010). Forest gardens are also designed to be easy to maintain with little input of resources and energy. While planning and establishing a forest garden there is a need to adapt to specific local conditions. The ground must be prepared in a way that makes best use of the available sunshine and water flowing through the area and the plants should be chosen and located to promote mutual growth. This requires knowledge and careful thought about the relationships between different kinds of plants, but also about the relationships between plants and animals and human activities. Forest gardens thus offer learning situations that contextualize this kind of interconnectedness.

Sustainable development depends on conservation and the development of ecosystem services (Millennium Ecosystem Assessment, 2005). This needs to be understood and acknowledged by the world's decision-makers and citizens when making decisions about land use in urban as well as rural areas. A number of studies discuss the significance of direct encounters with natural environments for children's concern with and understanding of the natural world (Chawla, 1999, 2009) and have pointed to the risks of emotional alienation/estrangement from nature as a consequence of global urbanization (Malone, 2007; Louv, 2008). It has been suggested that the emotional relationship or bonding with nature takes place before the age of 11-12 years old (Kellert, 2002; Sobel 2008). School gardening (Blair, 2009), forest schools (O'Brien and Murray, 2007; Waite et. al., 2015) and excursions (Sandell and Öhman, 2010) to more or less wild, rural areas are used in some parts of the world as a means to address these concerns about children's relationship to nature. However, many urban children do not have access to these kind of encounters with nature. Blair (2009) has suggested future research to report on creative means of maintaining school gardens over time and moving the workload away from teachers. The need to travel to green and forested places may cause barriers of transportation cost and travel time (Waite et al., 2015). A forest garden may be more accessible than forest schools/excursions and require less maintenance than a school garden. Thereby it may offer new educational opportunities through its potential to combine aspects of education in the classroom, school gardening and experiences of wilderness/cultivated landscapes.

There is a lack of research into the educational aspects of forest gardens. One reason for this might be that most urban forest gardens, have only been established in recent years. There are reasons to assume that forest gardens in urban areas respond to a variety of emotional, aesthetic, nutritional and recreational needs, for instance through opportunities for citizens to collect and enjoy edible plants. Participation in creating and maintaining forest gardens provides potential opportunities to emotionally and intellectually experience, practice and process knowledge about the interconnectedness and interactions between species, which in turn might increase the children's capabilities to handle complexities; this is important when making decisions about land use, 
particularly with regard to the conservation and development of ecosystem services. 'Ecosystem services', as a perspective on ecological processes, is highlighted in the Biology curriculum in grades 4-9 in Sweden (Swedish National Agency of Education, 2011), intended to provide students with insights into ecological processes. The ecosystem service approach to nature implies a unidirectional view about the purpose and value of organisms other than humans, insofar as the concept is described as follows:

'Ecosystem services' is a generic term for functions in nature that in different ways are beneficial to humans. Ecosystem services include products such as water, food and raw materials, and processes such as pollination of plants, water purification and circulation of nutrients." (The Swedish National Agency of Education, 2011, p. 21, our translation from Swedish).

Evidence suggesting that experiential contact with nature is necessary for child development has been presented by several authors (Sebba, 1991; Faber Taylor et al., 1998; Basile, 2000). While Faber Taylor and Kuo (2006) saw methodological weaknesses in most of these studies they concluded that "given the pattern of findings pointing in the same direction [...] it is more parsimonious to accept the fact that nature can promote healthy child development". Using the biophilia hypothesis (Wilson, 1984), nine types of basic "biocultural" values that people hold about the natural world and which are likely to have been adaptive during human evolution were described by Kellert $(1997,2002$, 2009). Kellert's typology, the result of many years of research into people's attitudes and values concerning nature, includes scientific, symbolic, aesthetic, utilitarian, moralistic, humanistic, dominionistic, negativistic and naturalistic values, each describing a particular "affinity" that humans have with nature. The values develop during childhood and represent "the creation of values, beliefs and moral perspectives", referred to as evaluative development (Kellert, 2002, p.120). This is of interest in our study, as experiential contact with the natural environment, especially for children aged 6-10 years old, has been suggested to be necessary for the development of different values, and consequently for normal maturation during childhood (Kellert, 2009).

Notably for 10-16-year-olds, the ecosystem services-perspective, which reflects the utilitarian values in Kellert's typology, is the only explicit perspective on nature expressed in the curriculum for Biology. For younger students, 6-9-year-olds, the curriculum does not explicitly point out any particular perspectives on nature that should frame learning about and in nature. However, implicitly there is a strong emphasis on what Kellert classified as scientific and symbolic values, such as naming and classifying (The Swedish National Agency of Education, 2011).

The concept of biophilia and Kellert's values of nature has recieved empirical support and form the basis of a considerable body of research (Gullone, 2000). In an investigation of educator's perceptions about the benefits for children of contact with nature, Maller (2009) used biophilia as a basis for a model of how activities involving hands-on-contact with nature influences children's mental, emotional and social health. Davis et al. (2006) applied Kellert's typology to findings in two outdoor learning case studies aimed at children three to 11 years old and found that Kellert's values relate to the pillars of learning formulated in UNESCOs report for learning in the $21^{\text {st }}$ century (Delors, 1996). More recently, Richardson et al. (2015) used Kellert's typology to analyses of results in a study investigating what aspects of urban landscapes can be valued as a route for people to connect to nature. Kahn (2003, p. 131) found "remarkably similar environmental moral reasoning" among 
children across diverse cultures and concluded that one explanation for this "is that that there are universal and invariant aspects of nature itself that give rise to and bound children's environmental constructions". For a critical discussion the biophilia hypothesis in relation to structuraldevelopmental theory, see Kahn (1997).

\section{Research aim}

This case study follows 27 seven to eight year old school children in the first six months of a three year project in which they participate in developing a forest garden.

The aim of the study is to investigate how the children reason with respect to different organisms' dependence on and relations to each other, themselves included. Specifically we ask:

How do the children describe their own relationships with other organisms, as well as the relationships between other organisms in the forest garden?

What values of nature are expressed by the children, and in relation to which situations in the forest garden?

In addition, we describe the contexts in the forest garden in which the different relationships and values appear.

\section{Method}

\section{Research setting}

The study is being carried out within the framework of a project entitled Bärfis, which translates into English as 'Stinkbug'. The Stinkbug project is aimed at young people and children in the south of Sweden. The project offers opportunities for several schools to visit and participate in the development of a model forest garden in Holma, Sweden, under the guidance of forest garden pedagogues. The most experienced of the forest garden pedagogues is leading the project and is a folk high school teacher (folk high schools are adult education institutions that do not grant academic degrees) with more than 20 years' teaching experience and academic interest in the humanities, natural sciences, behavioural studies and human ecology. The other forest garden pedagogues have different professional backgrounds such as organic farming on open farms, gardening, children's culture design and web design; however, none of them are teachers. Their educational backgrounds are, among others, in human ecology and environmental psychology.

The Stinkbug project encourages the children and their teachers to use their experience from the forest garden to develop smaller projects in their school yard and neighbourhood. In a funding application accepted by the Swedish Inheritance Fund, the forest garden project was described as a source of inspiration, a pioneer project aimed at promoting understanding that "the foundation of our existence is synergy, interacting mechanisms, in which the whole is greater than the sum of the parts."(p. 2 of the project description, our translation). Specific choices of examples of the interaction and relations between different organisms, abiotic factors and systems are made individually for each school class participating in the Stinkbug project. The forest garden is used as an example to explain the fundamental principles of our existence. The class participating in the present study has a focus on insects and their relations to parts of, as well as the whole system. The overarching aim of the Stinkbug project is formulated as "equipping children and young people to be active participants in building a sustainable society and creating a life of dignity" (p. 4 in project description, our 
translation). Holma forest garden was established in 2004 but is continuously undergoing further development. At the time that the current study took place it was the only forest garden in Sweden used for pedagogical purposes involving school children. The area set aside for forest gardening in 2003 was a total of $5000 \mathrm{~m}^{2}$ with a core area consisting of six equally-sized groves of fruit trees, nut and berry bushes and perennial herbs. Each of the groves have different characteristics. In addition to the groves, there is a pond, large nut trees, a pergola for climbers and an acidic soil plant area (Friends of the forest garden, n.d.).

\section{Participants}

Twenty-seven primary school students participating in the Forest garden project were asked to take part in our study in 2012. The children, about an equal number of boys and girls, were seven to eight years old and belonged to the same class. The recruitment area of the school has one of the lowest average income levels in the region and high unemployment. About half of the inhabitants in the area were born outside Sweden (Salonen, 2014). Parents and children were informed in writing by the researchers. Since most of the parents and children have a mother tongue/native language other than Swedish, the class teacher also informed both children and parents orally about the purpose and research conditions of the study. The parents were asked for permission to interview, record and take photos of their child/children. The children were also informed by the researchers that their participation was optional and that they had the right to withdraw from the study whenever they liked. The participants were divided into four groups, each working with a particular mini-project within the larger forest garden project. Each of these mini-projects was scheduled to run for three years under the supervision of the pedagogues. The mini-projects are: the butterfly bed, the stone wall and the dry meadow. In addition to these three mini-projects there are optional activities for the children to choose from e.g. picking berries, making jam, cutting wood. Before the visits to the forest garden the children had been taught characteristics of insects in classroom by their class teachers.

\section{Data collection and analysis}

\section{Data collection}

In order to get a broad understanding of children's expressions of relations to and between other organisms including values concerning nature, we applied a variety of data collection methods. We sought to capture what was spontaneously expressed by the children in the situations in the forest garden. At the same time, we sought to investigate the children's reflections on their activities in the garden after their visits to the garden. We did this by showing the children photos of their garden visit activities, and asking them to discuss their ideas about the purposes of the activities.

Participatory observations documented the children's actions, their priorities, spontaneous talk, emotional expressions and the children's communication with the educators. This was documented by means of field notes, photographs and digital audio and video recordings made during two days of children's visits (March and September 2013) to the forest garden, each visit lasting one day. The children also visited the forest garden one day in May 2013. The total time of audio recordings was three hours and two hours for observations in the forest garden and stimulated recall interviews, respectively. The total time of video recordings from the forest garden was ten minutes.

Photographs of the activities in the forest garden were also used in a second phase of data collection: stimulated recall interviews (Stough, 2001). The stimulated recall interviews were carried out in December 2013, three months after the children's third visit to the forest garden. In these interviews 
the photos from the activities were used as reminders of what had happened in the forest garden. The children were asked to comment on the situations in the photos. They were asked about what they and their classmates were doing and for what purpose. The stimulated recall interviews were conducted in focus groups in class rooms, which gave the participants opportunities to ask each other questions, to remind each other of events and discuss them and to let the conversation take new and unexpected turns (Kitzinger and Barbour 1999; Wibeck, 2010). The focus groups were identical to the mini-project groups.

Although each group of children (the Ants, the Beetles, the Butterflies and the Ladybugs) was mainly involved in one of the mini-projects, all the children were familiar with what was going on in the other projects as well since they were working in close proximity to each other. For this reason, the groups were shown pictures from the other projects and asked to relate to them in the stimulated recall interviews.

\section{Data analysis}

Data analysis was performed using a combination of qualitative and semi-quantitative methods.

Initially, the full body of data was subjected to qualitative content analysis (Patton, 2002). Situations where children in some way related, either verbally or bodily, to the natural environment in the forest garden were identified in recordings and field notes and transcribed in Swedish. Recordings from stimulated recall interviews were transcribed in their entirety and analysed similarly. Each miniproject or activity was analysed separately in order to identify differences between them. Excerpts illustrating ideas of relationships and the values of nature (Kellert, 2002) were chosen for the article and translated into English. Symbolic values were not analysed.

Secondly, the transcripts were analysed semi-quantitatively with respect to the occurrence of descriptions involving different kinds of relationships between organisms, using pre-determined categories to describe these relationships (see Table 1). The occurrence of a specific relationship was interpreted as either absent (not mentioned by any child), rare (mentioned occasionally by one or two children), common (mentioned several times by more than one child), or very common (mentioned many times by two or more children). The occurrence of expressions that could be described as belonging to any of the nine values of nature (Kellert, 2002) was analysed in a similar way (Table 2).

\section{Results}

The results obtained from the qualitative content analyses of the stimulated recall interviews, the field notes and the recordings are presented for each of the mini-projects. For each mini-project data from the observations in the forest garden are followed by data obtained when pictures relating to that mini-project were shown during the stimulated recall interviews. Figures used to denote children in excerpts do not identify specific individuals, but only distinguish individuals in a given excerpt. In the later part of the section, the results from the semi-quantitative analysis of expressions of relationships between organisms and values of nature are presented under respective headings. 
The butterfly bed was prepared with the intention of supporting pollinating insects such as butterflies and bees.

\section{Observations from the butterfly bed}

During the visit in March the pedagogue first had the children taste and smell dried violets (Viola sp.), chamomile (Matricaria chamomilla) and marigolds (Calendula officinalis). She offered the children herbal tea made from some of these plants and later took out a jar of honey and talked with the children about how bees were involved in making it. As an introduction to the preparation of the butterfly bed, the pedagogue asked the children about the butterflies' needs:

Pedagogue: We are going to make something that the butterflies like. What do you think it could it be?

Child 1: Maybe we can build a butterfly house for them.

Pedagogue: I'll give you a little clue. Something which grows that the butterflies like; something which grows all by itself.

Child 1: Maybe we could plant flowers.

As can be seen from this excerpt, when talking to the children the pedagogue emphasized their role in helping the butterflies rather than the opposite perspective - the butterflies helping humans to produce fruit through their pollinating activities. The child responded by expressing a wish to help the butterflies by building a butterfly house. This wish was also expressed by another child working in this mini-project.

Later during the day the pedagogue asked Child 1 to describe the mini-project to a passer-by:

Pedagogue: Do you want to describe what we are doing here?

Child 1: We are going to build a house for a butterfly. [...] And we shall also look for butterflies to put in the house, so that they can live there a little and...

Pedagogue: And what was it that we are going to plant for them?

Child 1: Flowers, here, as a garden. [...] And in there we are going to make it clean, we are going to tidy up, remove the sticks and what is there.

The wish to "tidy up and make it clean for the butterflies", was expressed on several occasions by Child 1.

The children continued their work by drawing maps of how they wanted the butterfly bed to appear, and made measurements and marked out a place for it in the field. They then planted seeds of marigold and borage in pots and placed these in a greenhouse.

On the second visit to the forest garden, the children prepared the ground for the butterfly bed by spreading newspapers and leaves to create favourable growing conditions, e.g. by preventing the 
spread of weeds. During this work the children encountered worms, spiders and millipedes. Together with the pedagogue they planted several species of plants: orpine (Hylotelephium telephium), sweet violet (Viola odorata), catnip (Nepeta cataria), lemon balm (Melissa officianalis), bluebell (Campanula sp.), lady's mantle (Alchemilla sp.) and marigold (Calendula officinalis), etc. They tasted and smelled various plants that had already come up in the forest garden.

On the third visit the children first observed how their plants were doing. They collected seeds from marigold and picked and tasted raspberries (Rubus ideus), blackberries (Rubus nessensis), grapes, Japanese silver berries (Elaeagnus umbellata) and mushrooms. The children were looking out for different insects, especially butterflies, and found larvae of Large White butterflies. While working on the project the children also showed a great deal of curiosity about the surrounding environment, as when on one occasion they thought they had found a bird's nest.

\section{Stimulated recall from the butterfly bed}

In two of the groups, even before any specific question was asked, the children's response to the picture (Figure 1) was that the flowers were beautiful. The children mentioned which flowers they thought were the most beautiful. Some of the children described how they proceeded when preparing the butterfly bed, how they first covered the ground with newspapers and later with straw. They also described how they planted seeds which were contained in small paper bags.

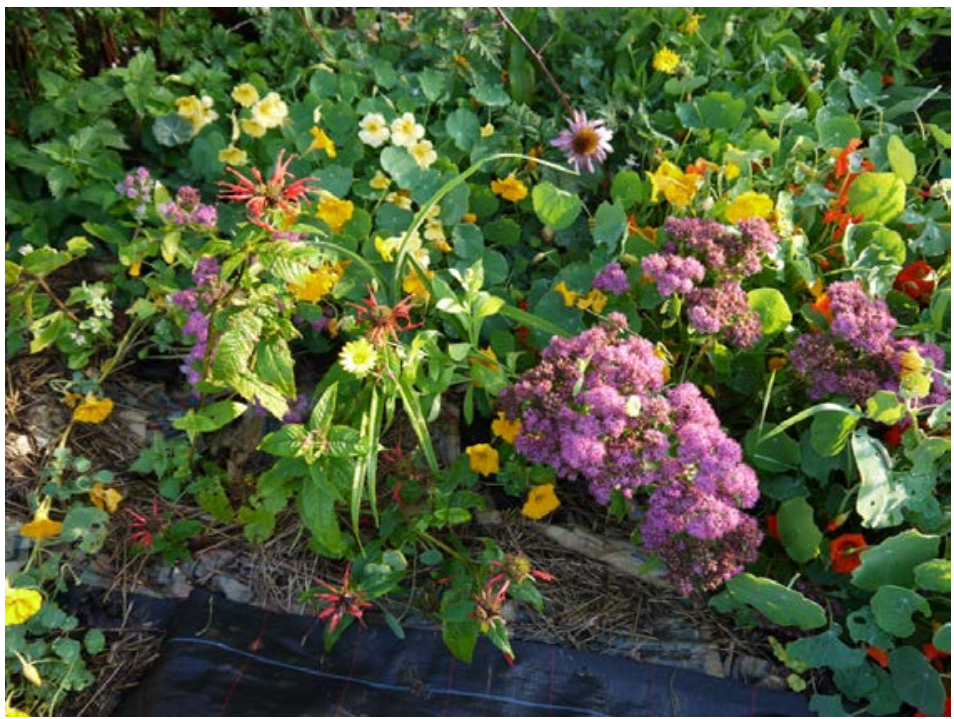

Figure 1. Photograph of the butterfly bed used during stimulated recall.

The children explained that the reason they planted the flowers was that bees, butterflies and bumblebees would come and eat from them; one child also mentioned wasps. They said that butterflies ate from the flowers (the children mentioned either sucking or eating by using the tongue or proboscis). The children gave different answers about what the insects ate from the flowers: nectar, pollen or "something yellow". A few children explained how insects took pollen from one flower to another, which made the plants grow. An excerpt from the Bumblebees illustrates this: Interviewer: Why do you think we planted flowers? Child 1: Because when the bees come they should get...I don't remember what it's called. 
Child 2: When the flowers have grown, when they (the bees) want more.... nectar.... they take pollen from these, they get it on themselves [...] And when they go over they shake it off. And then it comes on the plants and they grow.

In several of the groups the children said that they benefited from the butterfly bed because the flowers were beautiful and because it gave us honey. One child in the Butterfly group said that butterflies were important for us to get oxygen, to be able to breathe. The following excerpt is from this interview:

Interviewer: Is the butterfly important to us?

Several children: Yes!

Child 1: I think it is called oxygen. We must get oxygen...to breathe.

Interviewer: How do you mean?

Child 2: There wouldn't be any butterflies.....nothing. If we killed all the butterflies on earth we would die.

Interviewer: Why?

Child 2: 'Cause if you kill all the animals you don't get oxygen.

As Child 2 did not give any further thoughts about the relationship between animals and oxygen production, it was not explained in this interview why animals were necessary to provide us with oxygen.

\section{The stone wall}

The purpose of building a stone wall in the forest garden is twofold: to enhance the growth of plants that need heat and to create micro-environments for hibernating insects so that they could function mainly as pollinators, but also as predators of aphids and other insects that might cause damage when present in large numbers. Stones were placed in gabions (wire mesh baskets) together with pieces of wood that act as a substrate in which the larvae develop.

\section{Observations from the stone wall}

On the first visit in March, the pedagogue started by asking the children (Beetles group) if they knew about the purpose of the forest garden. The children said it was to take care of the insects and the plants, to prevent them from being destroyed. They also said that plants needed to be taken care of to grow and not wither. The pedagogue then told the children that the forest garden could provide us with food such as apples and how insects help with plant pollination and thus help us in producing apples, etc.

The pedagogue had the children touch a stone and feel the difference in temperature between the sunlit and shaded sides. On which side would the children like to be, the pedagogue asked? The discussion led on to the insects' needs and to the reasons for making the stone wall. By building the wall the children would help the insects, the pedagogue said, and in addition plants needing heat would thrive near the wall. The children took part in planning the stone wall by drawing maps and taking measurements in the field. The map was named "A wall for plants and insects". For the 
remaining time the pedagogue told the children about different insect groups and showed pictures of bugs, true flies, beetles and hymenopterans (ants, solitary bees, communal bees and wasps). The children immediately recognized the stink-bug, the namesake of their project. They started making nests for solitary bees by drilling holes in pieces of wood. The other group of children involved in this mini-project (the Ants) made nests for bumblebees from pots that they inserted in the ground.

The second visit in May started with a repetition of insect-plant relations and the purpose of the stone wall. The children looked for insects and made drawings of bumblebees. They started the construction of the wall by transporting stones to the gabion in a wheelbarrow.

The third visit in September started by recalling what had previously been done by the groups (Beetles and Ants) in relation to the mini-project. The children in both groups remembered that they were building a stone wall and that they had drawn a map. The children specifically said they had made nests for bees and bumblebees. The children also remembered that on the previous visit they had been carrying stones, seen bees and drawn pictures of them. One child said they had been collaborating when they carried stones. Another child said they had been measuring distances (for the construction of the wall) and playing on the ice of a small pond, referring to the first visit in March.

When asked if they remembered why they had built the wall, one child said it was so that they would not see the houses behind. Another child remembered that the wall contained small nests in which animals could live. The pedagogue mentioned the role of the wall in stimulating plant growth and this led to a discussion of the heat-preserving properties of the wall. The children were asked if they remembered how it felt to touch a (sunlit) stone on their first visit to the forest garden. They said it was a nice feeling but no child mentioned it was warm; one child instead referred to the moss that was growing on the stone ("There was something on it"). The pedagogue reminded them that the stone had been warm to touch, and continued asking who would benefit from a warm wall:

Pedagogue: And why do you think we want a warm wall?

Child: Because then the insects will think it's comfortable.

The children continued working on the wall. When the pedagogue asked them how to organize the work in the best way, one child said "by collaborating", in line with what the pedagogues had stressed earlier when talking to the children. One child repeated that they were going to "work hard", a statement that had also been made by the pedagogue.

\section{Stimulated recall from the stone wall}

When shown the picture of the stone wall under construction (Figure 2) during the stimulated recall, some of the children who had been directly involved in the project described vividly how many stones they had carted and how the wheelbarrow had overturned on one occasion - their gestures and mimics of this and similar situations showed their joy and enthusiasm at the memories of working on the stone wall. 


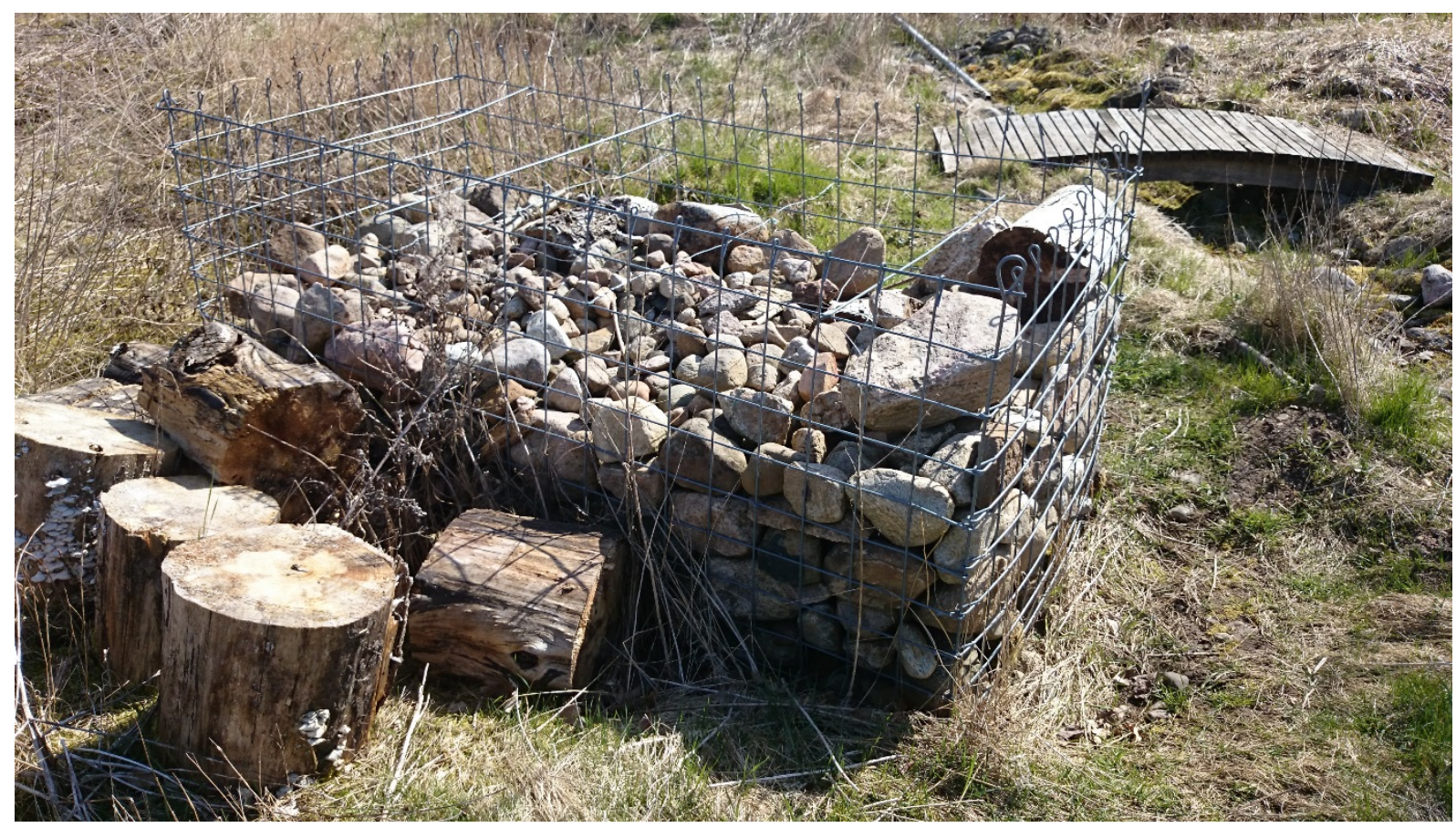

Figure 2. Photograph used during stimulated recall interviews showing the stone wall.

Asked why they had built the wall, the children answered it was to help the insects. Only when the interviewer specifically asked if not only they themselves, or other humans, could benefit from the wall in any way other possibilities vaguely emerged (from one child), as demonstrated in this excerpt from an interview with the Ladybugs:

Interviewer: Is it just to be kind to the insects (you are building the wall)?

Child 1: Yes. Not only that. We care about the insects.

Child 2: And take care of them.

Child 1: As our pets.

Interviewer: Only because of that? No other uses?

Child 3: So that they can fly.

Interviewer: Can you think of anything that we can have use of from the insects?

Child 4: So that we can live.

Why insects are important for the life of humans was not further elaborated on by this child. The following excerpt from an interview with the Beetles further exemplifies how the children looked upon the function of the stone wall:

Interviewer: Do we benefit from the insects living inside (the wall)? Is it just to be kind to them or do we have any use of it ourselves?

Child 1: So that they are comfortable. 
Interviewer: Don't we have any use for the insects at all. Why are we building the wall? Just to be kind to them?

Child 2: So that the insects will come.

Child 1: So that no spider will come and eat them.

Child 2: Those bumblebees and ants and such [...] they want a home and they can't build it themselves because they don't have any hands, they have tiny hands. So humans can build it for them.

No child mentioned the effects the stone wall could have on the plants in the forest garden, directly or indirectly.

To summarize, the children involved in this mini-project described it as a joyful activity and put emphasis on what they had been doing physically. They, as well as the other children, regarded the construction of the stone wall first and foremost as help for the insects and not as beneficial to the forest garden as a whole.

The dry meadow

A dry meadow was created in the forest garden to host plants adapted to low-nutrient soils and dry conditions. Such plants attract a number of insects that can act as important pollinators in the forest garden.

\section{Observations from the dry meadow}

On the first visit an instructor was talking with the children about the importance of insects and their interaction with plants and how the meadow could be constructed. The children started preparing the dry meadow by first covering the ground with newspapers to prevent the growth of weeds, then putting sand on top. Some plants adapted for dry conditions were planted in the sandy area but most of the area was left uncovered. The work continued on the second and third visits with the aim of expanding the area of the dry meadow and at the same time creating a pathway through the dry sandy area. The children pruned small bushes with secateurs to make it possible to flatten newspapers on the larger area. The children were very eager to work physically and to use the secateurs. Their eagerness to work and do pruning were expressed in various different ways. The most hardworking trimmer repeated, while struggling with a small birch plant, about 30 centimetres high:

\section{- I will kill you!}

This child worked very seriously and showed appreciation when he was given a pair of gardening gloves. The gloves reminded him of an important event in his life when he and his father and uncles/cousins had built a house, "a real house", he said.

The children got spades and buckets to move the excess sand that was produced while digging pathways in the sandy area created during the first visit. The children were asked to discuss how the pathways were going to be designed through the dry area. The children suggested straight lines while the pedagogues preferred a curved, organic design. The pedagogues argued that it would be much easier to reach the plants with the curved design and the children seemed, after some arguing, reluctantly convinced. At the beginning of the construction work they had some difficulties in 
cooperating. They wanted to keep the buckets for themselves to carry, but as they got tired they started to ask others to help. After a while they carried the buckets in pairs and the work became smoother.

\section{Stimulated recall from the dry meadow}

When shown the pictures from the dry meadow (Figure 3) the children said that they were making a road or a path. One child said the path was to avoid treading on the plants. They said that they put newspapers on the ground to prevent plants growing. At the time of the stimulated recall the intention of the project seemed to be unclear to the children, as shown by the following excerpt from the Ladybugs:

\section{Interviewer: Why are you doing this?}

Child 1: So that the plants won't grow.

When the interviewer asked if there was only going to be sand here, Child 1 confirmed this.

$$
\text { Interviewer: Nothing else? }
$$

Child 1: Yes, and newspapers...and nothing else. The newspapers mustn't be visible.

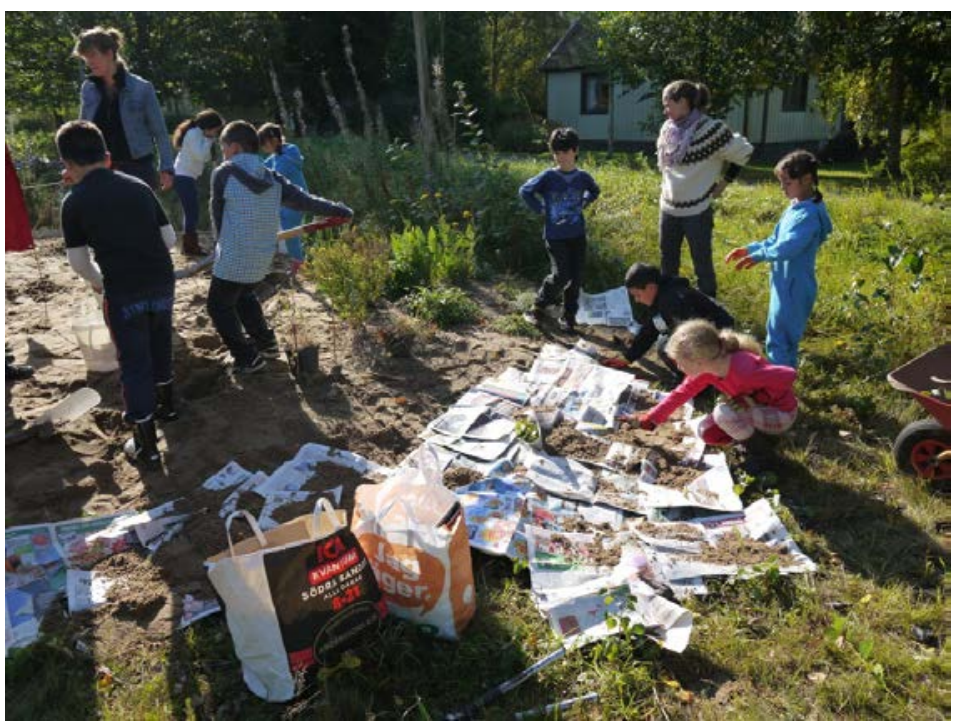

Figure 3. Photograph used during stimulated recall interviews showing children working at the dry meadow.

\section{Optional activities}

\section{Observations}

Each group of children went for a walk with a pedagogue in the forest garden with the main aim of looking for flowers with insects on them. A few children in one of the groups had encounters with stinging nettles (Urtica dioica): "I don't even want to be close to nettles", one child said. "Neither do I", another child responded. 
A couple of children started talking about a grass snake (Natrix natrix) that they had observed in the forest garden on the visit in May. One child mentioned that their teacher had almost fainted when she saw it. On the contrary, none of the children involved expressed awe in relation to this experience.

Upon approaching a bush of silver berries the children knew they should pick the red, ripe berries: "Look, in there, the red ones are ripe"; "the red ones taste really good". The pedagogue had the

468 children taste unripe berries as well; the children found these sour, one child still wanted to try 469 tasting twice. The children were also curious to taste Aronia berries (Aronia sp.): "You get a dry 470 feeling in the mouth", one child said.

471

\section{Stimulated recall from berries and berry picking}

473 The figures of berries/berry picking (Figures 4 and 5) do not relate directly to any of the mini-projects 474 but were chosen for the stimulated recall to represent one of several optional, self-selected activities 475 in which the children took part during visits to the forest garden.

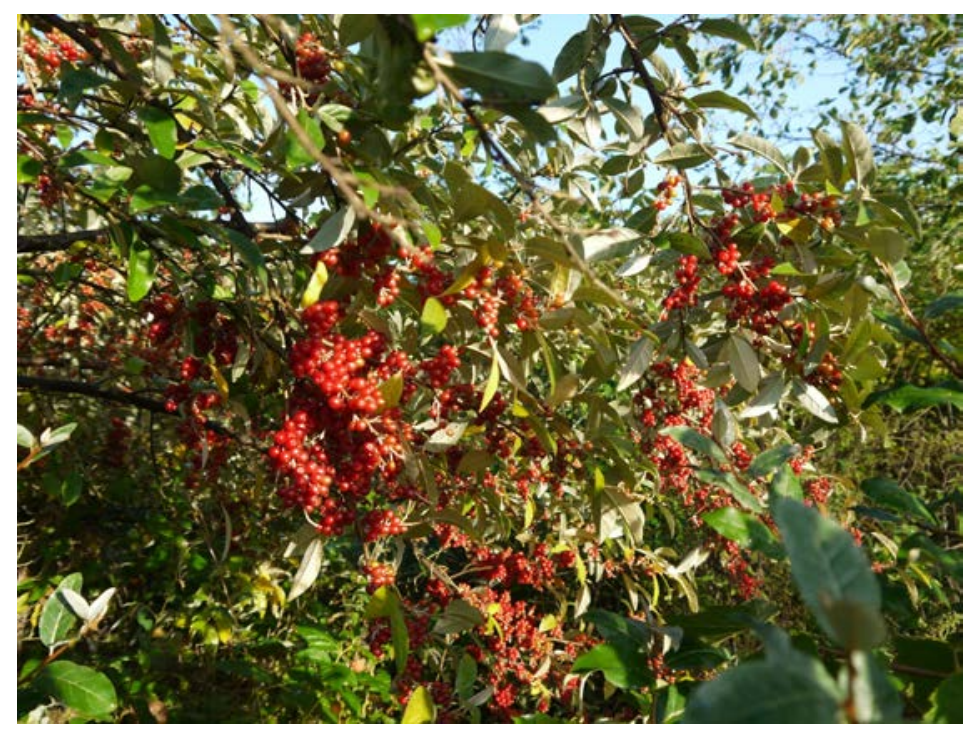

477 Figure 4. Photograph used during stimulated recall interviews showing silver berries. 


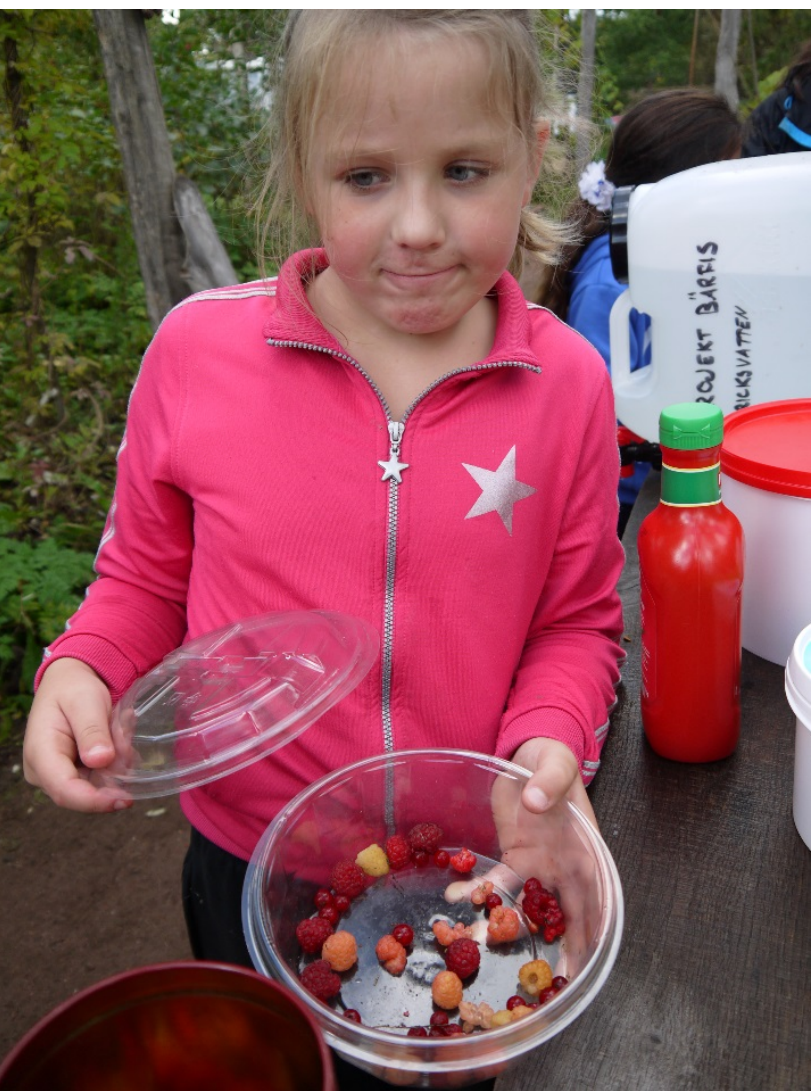

Figure 5. Photograph used during stimulated recall interviews showing harvest of berries.

480

481

482
The berries seem to have made a big impression on the children. Children in all five groups first related to jam which they had made from the berries during their third visit to the forest garden. Many of the children expressed joy in relation to picking berries, despite the fact that several of them also said that they didn't like the taste of the silver berries.

The interviewer raised the question of how berries develop. In all four groups the children said that to obtain berries a seed or kernel has to be planted in the soil. One child stressed the importance of cleaning the kernel before planting it, to avoid the berry becoming infected with bacteria. Several children said that the seed grew to a bush or tree from which new berries would grow. In addition to soil, water was needed for the bush to grow. The need for sunlight was also mentioned in two of the groups.

The importance of the flower in the production of berries seemed unclear to the children. According to a few children the flower came after the berry, as illustrated by the following excerpt from the Ladybugs group:

Interviewer: Which comes first? The flower or the berry?

Child 1: It's the flower that comes last...last.

Interviewer: Do you agree on that? First berry and then flower?

Child 2: Yes, and then the bud comes from the flower. 
The involvement of insects in the production of berries was not mentioned by any child. Prompted by a leading question, one child mentioned that insects transfer something (pollen wasn't mentioned) to plants that makes plants grow, but was referring to the growth of plants rather than the development of fruits from flowers.

\section{Summary of results}

\section{Relationships between organisms}

Relationships between different organisms described by the children and their occurrence in relation to the different mini-projects are summarized below (Table 1). Relationships rarely included more than two organisms. The most common relationships described were between animals (excluding humans) and plants, between humans and animals, and between humans and plants. The animals mentioned were with a few exceptions insects. Relationships between different animals were very rare. In relationships between humans and animals the direction of the relationship was almost exclusively directed from human to animal. (Table 1).

The specific mini-projects in the forest garden had a great influence on the type of relationships that were described by the children. For example, relationships between humans and animals were common in relation to the stone wall and butterfly bed but absent elsewhere, and only human-toplant relationships were described in relation to the dry meadow (Table 1). There were also many differences between observations and stimulated recall interviews; e.g. in relation to the butterfly bed, descriptions of animal-to-plant and plant-to-human relationships were common in interviews but absent during observations (Table 1 ).

\section{Table 1. Occurrence of different relationships between organisms described by children during} observations and stimulated recall interviews.

Occurrence of descriptions designated: absent (0); rare (1); common (2); very common (3). * Observations in this category relates to several optional activities, not only berry picking.

\begin{tabular}{|l|l|l|l|l|l|}
\hline \multirow{2}{*}{$\begin{array}{l}\text { Type and direction of } \\
\text { relationship }\end{array}$} & \multicolumn{3}{|c|}{$\begin{array}{l}\text { Occurrence during observations } \\
\text { /stimulated recall interviews }\end{array}$} & \multirow{2}{*}{$\begin{array}{l}\text { Examples of described } \\
\text { relationships }\end{array}$} \\
\cline { 2 - 5 } & $\begin{array}{l}\text { Stone } \\
\text { wall }\end{array}$ & $\begin{array}{l}\text { Berries } \\
\text { and opt** }\end{array}$ & $\begin{array}{l}\text { Butterfly } \\
\text { bed }\end{array}$ & $\begin{array}{l}\text { Dry } \\
\text { meadow }\end{array}$ & \\
\hline Animal $\rightarrow$ Animal & $0 / 1$ & $0 / 0$ & $0 / 0$ & $0 / 0$ & Spiders eat insects \\
\hline Animal $\rightarrow$ Plant & $1 / 0$ & $0 / 1$ & $0 / 2$ & $0 / 0$ & $\begin{array}{l}\text { Insects help plants to grow; } \\
\text { insects transfer pollen to plants }\end{array}$ \\
\hline Plant $\rightarrow$ Animal & $1 / 0$ & $1 / 1$ & $1 / 2$ & $0 / 0$ & $\begin{array}{l}\text { Plants provide nectar and pollen } \\
\text { to insects }\end{array}$ \\
\hline Animal $\rightarrow$ Human & $1 / 0$ & $0 / 0$ & $0 / 1$ & $0 / 0$ & \begin{tabular}{l} 
Insects make honey \\
\hline Human $\rightarrow$ Animal
\end{tabular} \\
\cline { 1 - 4 } & $2 / 2$ & $0 / 0$ & $2 / 2$ & $0 / 0$ & $\begin{array}{l}\text { Children take care of insects; } \\
\text { children build nests and provide } \\
\text { shelter to insects }\end{array}$ \\
\hline Human $\rightarrow$ Plant & $1 / 0$ & $0 / 1$ & $1 / 2$ & $2 / 2$ & $\begin{array}{l}\text { Children take care of plants; } \\
\text { children plants seeds and provide } \\
\text { water; children need to suppress } \\
\text { weeds }\end{array}$ \\
\hline
\end{tabular}




\begin{tabular}{|l|l|l|l|l|l|}
\hline Plant $\rightarrow$ Human & $1 / 1$ & $2 / 2$ & $0 / 2$ & $0 / 0$ & $\begin{array}{l}\text { Plants provide berries to eat and } \\
\text { make jam; plants are beautiful; } \\
\text { nettles sting children }\end{array}$ \\
\hline
\end{tabular}

522

523

524

525

526

527

528

529

530

531

532

533

534

535

536

537

538

539

540

541

\section{Values of Nature}

Table 2 summarises to what extent the nine values of nature (Kellert, 2002) were expressed in relation to the different mini-projects during observations and interviews. Scientific values were the most common, but usually in response to a question from an adult. Humanistic values were commonly expressed in relation to the stone wall and butterfly bed, as were aesthetic values. Naturalistic values were common to very common during observations in all situations in the forest garden, but completely absent during interviews. Utilitarian values were fairly common during stimulated recall interviews, especially in relation to berry picking. Negativistic values were expressed in relation to nettles during free activities like berry picking, but were mostly absent elsewhere. Dominionistic values were rarely expressed in relation to cutting and suppressing weeds at the dry meadow but was absent in other situations. Symbolic and moralistic values were absent or only rarely expressed, respectively.

Table 2. Occurrence of different values of nature expressed by children during observations and stimulated recall interviews.

Occurrence of expressions designated: absent (0); rare (1); common (2); very common (3). *Observations in this category relates to several optional activities, not only berry picking.

\begin{tabular}{|c|c|c|c|c|c|}
\hline \multirow[t]{2}{*}{$\begin{array}{l}\text { Values of nature } \\
\text { (Kellert, 2002) }\end{array}$} & \multicolumn{4}{|c|}{$\begin{array}{l}\text { Occurrence during } \\
\text { observations /stimulated recall interviews }\end{array}$} & \multirow[t]{2}{*}{ Context and examples of expressions } \\
\hline & $\begin{array}{l}\text { Stone } \\
\text { wall }\end{array}$ & $\begin{array}{l}\text { Berries } \\
\text { and opt.* }\end{array}$ & $\begin{array}{l}\text { Butterf } \\
\text { ly bed }\end{array}$ & $\begin{array}{l}\text { Dry } \\
\text { meadow }\end{array}$ & \\
\hline Aesthetic & $1 / 0$ & $2 / 2$ & $2 / 2$ & $0 / 0$ & $\begin{array}{l}\text { In relation to flowers, cones, berries, a } \\
\text { spider and net, a snail's shell }\end{array}$ \\
\hline Dominionistic & $0 / 0$ & $0 / 0$ & $0 / 0$ & $1 / 1$ & Suppressing weeds, cutting vegetation \\
\hline Humanistic & $2 / 2$ & $0 / 0$ & $2 / 1$ & $0 / 0$ & $\begin{array}{l}\text { Taking care of insects and, building } \\
\text { nests for insects }\end{array}$ \\
\hline Moralistic & $0 / 1$ & $0 / 1$ & $0 / 1$ & $1 / 1$ & $\begin{array}{l}\text { Children say plants mustn’t be treaded } \\
\text { on }\end{array}$ \\
\hline Naturalistic & $2 / 0$ & $3 / 0$ & $2 / 0$ & $0 / 0$ & $\begin{array}{l}\text { Curiosity expressed to insects, berries, } \\
\text { a grass snake, a bird's nest, etc. }\end{array}$ \\
\hline Negativistic & $0 / 0$ & $1 / 0$ & $1 / 0$ & $0 / 0$ & In relation to nettles, an earwig \\
\hline Scientific & $3 / 3$ & $2 / 3$ & $2 / 3$ & $0 / 1$ & $\begin{array}{l}\text { Descriptions of ecological } \\
\text { relationships, naming of organisms }\end{array}$ \\
\hline Symbolic & - & - & - & - & Not analysed \\
\hline Utilitarian & $1 / 1$ & $1 / 2$ & $1 / 1$ & $0 / 0$ & $\begin{array}{l}\text { Plants provide fruits, plants provide } \\
\text { honey }\end{array}$ \\
\hline
\end{tabular}


543 The values of nature that were most commonly expressed by the children were scientific, humanistic, aesthetic and naturalistic values (Table 2 ), whereas utilitarian values, and especially moralistic, dominionistic and negativistic values, were expressed much less often. According to Kellert (2002) utilitarian, dominionistic and negativistic values typically develop between three and six years of age. Humanistic, symbolic, aesthetic and scientific values develop most rapidly between six and twelve years of age, while at the same time utilitarian, dominionistic and negativistic values diminish in importance. A third stage between 13 and 17 years of age involves "a significant expansion in moralistic, naturalistic, and ecological components of the scientific values of nature" (Kellert, 2002, p. 135). On the other hand, in their studies of three-11 year old children, Davis et al. (2006) found that aesthetic, naturalistic and negativistic values may develop before three years of age, and humanistic values soon thereafter. Their data also suggested that dominionistic and utilitarian values may first develop between six to 12 and 13 to 17 years of age, respectively. From our own study we can conclude that those values that were most prominent among the seven to eight year old children, with the exception of naturalistic values, were those that Kellert (2002) suggests develop most rapidly between six and 12 years of age (we chose not to analyse the expression of symbolic values, however).

As the scientific value, Kellert (2002) refers to the ability to empirically and systematically study and

560

561

562

563

564

565

566

567

568

569

570

571

572

573 understand nature. He suggests that the development of this ability is advantageous for the development of cognitive capabilities such as intellect, problem-solving and critical thinking, as well as for the development of respect for and appreciation of nature. Several studies have supported the view that contact with nature promotes cognitive development in children (Faber Taylor and Kuo, 2006). The mini-projects differed considerably in respect to what relationships (Table 1 ) and values of nature (Table 2) they promoted the children to describe. The dry meadow held an exceptional position in that fewer descriptions and expressions were observed there than in the other places, and that children responded less about who could benefit from this mini-project and why in the interviews. The main activity during the dry meadow project was the physically demanding work to prune and to cover the vegetation with newspapers and sand. The link between this and the benefit for insects of a future dry meadow may have been difficult for the children to perceive, despite the pedagogues initial explanations. The more direct and straight forward link between building a home for insects in the form of a stone wall and the benefits for insects was easier for the children to perceive and talk about. This shows the importance of activity and context to what understanding of relationships and values of nature they promote.

In the present study, scientific expressions indicating cognitive knowledge of ecological relationships were observed during the actual activities in the forest garden as well as during the stimulated recall interviews (Table 2). In general, expressions of this type were most common as responses to questions posed to the children. The children's expressions and explanations of relationships between organisms in the forest garden usually involved no more than two organisms, or types of organisms (Table 1).

Descriptions of relationships involving two or more animals (excluding humans), or types of animals, were very rare. One of the rare examples included spiders eating insects (Table 1). The scarcity of this kind of description indicates that the situations did not prompt discussions about feeding relationships or symbiotic relationships in general, between animals in the forest garden. 
Descriptions of relationships between insects and plants were common during stimulated recall interviews in relation to the butterfly bed. These usually described the unidirectional relationship between an insect and a plant, although there were examples of relationships directed both from plants towards insects and vice versa (Table 1). Examples included children's descriptions of a butterfly eating from plants using its proboscis, and phrases like "insects are helping plants to grow". The focus the pedagogues put on how insects assist in pollination as well as the children's preparations in school prior to the visits to the forest garden, may explain why descriptions involving insects and plants were frequent during stimulated recall interviews.

Descriptions about relationships between humans and another type of organism were common in relation to the butterfly bed and stone wall (Table 1). As with the relationships between animals and plants these were most frequently described as taking place only in one direction. It is noteworthy, however, that relationships involving humans and other animals were described almost exclusively as directed from human to animal (Table 1). Relationships between humans and plants were directed both from human to plant and vice versa: a seed placed in the ground by a human would grow into a plant; a tree in the forest garden would provide fruit that could be eaten by humans; flowers would provide honey to humans (insects not specifically mentioned). The latter two examples reflect utilitarian values (Kellert, 2002), but expressions of such values were relatively uncommon except in relation to berry picking (Table 2; discussed in more detail below in relation to ecosystem services). Although the pedagogues frequently talked about how the insects could help the children by increasing the production of berries and fruit, they even more strongly emphasized how the children could help other organisms in their mini-projects. This was also amplified by the activities in the miniprojects that were designed to help the insects. The harvesting of berries and fruit was not part of a mini-project and the importance of insects for a good harvest never became as obvious and completely connected to the children's own work as the activities in which they were helping the insects in the forest garden.

More complex relationships between organisms were rarely observed in the children's descriptions. The relatively low level of complexity was exemplified by the fact that the descriptions of relationships were usually unidirectional at a given time and involved no more than two organisms or type of organisms. Occasionally, descriptions of relationships included more than two organisms, such as when a child said that the reason they were building the stone wall was "So that no spider will come and eat them", referring to the insects hiding from spiders inside the stone wall. In this case the relationship involved the children themselves (who built the wall), the insects and the spider. We do not find support in the data for children's understanding of humans' dependence on insects, except in two cases in relation to the butterfly bed: one child proposed that insects were important "so that we can live" and another child claimed that killing all animals would deprive us of oxygen. Whether these explanations were limited by the children's language, stage of maturity or the learning situation is still an open question.

Together with the observation that the children almost always described a relationship between a human and an animal from the direction of the human towards the animal, the most prominent feature of the children's descriptions of the relationships was how they cared for the organisms in the forest garden, not least the insects. Statements of the type "we care about the insects" and explanations of why they built the stone wall ("Because the insects will think it's comfortable") were common and illustrate the emotional bonding with nature that Kellert (2002) classifies as the 
humanistic value of nature (Table 2). This value is suggested as being instrumental in the development of capacities for receiving and giving affection, forming intimate and companionable bonds, as well as expressing trust and cooperation (Kellert, 2009). Kellert claims that this kind of bonding with nature "focuses on familiar and domesticated animals" (p.117), but in the forest garden there are no such animals. Instead the children in the study became acquainted with undomesticated and unfamiliar animals such as the different insects. They called them their "pets" and talked about taking care of the insects. When they said, for instance, how they wished to "tidy up and make it clean for the butterflies" and plant beautiful flowers like a garden for them, the children showed signs of identification with the butterflies. Similar signs of identification were observed in relation to the stone wall for insects. Through such identification with animals, people can achieve "a sense of belonging" (p. 117). According to Shepard (1996, p. 4) by identifying with animals "the child discovers a common ground with other beings despite external differences between himself and them."

Aesthetic values were commonly expressed by the children in relation to the flowers, shells, berries, etc., that the children encountered in the forest garden. During the stimulated recall interview they responded to the pictures of the flower bed by showing appreciation for the beauty of the flowers (Table 2). These results are consistent with research about primary school children's relationships to plants in Finland where girls especially found the beauty and joy of plants important (Laaksoharju and Rappe, 2010). According to Kellert (2009) the ability to experience the aesthetic values of nature "can enhance people's capacities for curiosity, imagination and creativity, as well as their ability to recognize order, harmony, symmetry and balance". The children's interest in the grass snake they had seen, a bird's nest, spiders and unfamiliar berries of various colours are examples of the children's curiosity about the natural world (naturalistic values, Table 2), also thought to be of great importance for the development of the imagination and creativity, as well as self-confidence, selfesteem and peace of mind (Kellert, 2002). In contrast to the situation in the forest garden, expressions of naturalistic values were not observed during the stimulated recall interviews, indicating that the interview did not stimulate curiosity about the natural world in the children.

In contrast, there were very few negativistic descriptions, i.e. manifestations of avoidance, aversion or anxiety in relation to the forest garden. A few children, however, expressed awe in relation to stinging nettles. Similarly, expressions of dominionistic values were only observed on a few occasions, in the group of children who were working on the dry meadow (Table 2). Here, a few children expressed the importance of suppressing the growth of plants by putting newspapers on top of them; one boy emphatically stated his command over the tiny birch plant which he subsequently cut down, so that he could cover the ground with newspapers and sand. Examples of moralistic values were also scarce, but were observed in a few cases when the children repeated what the pedagogues had told them, that they must not tread on the plants. The forest garden probably also contributed to the children's language development (symbolic values), but the method used in this study did not provide any data for conclusions in this regard (Table 2). A longer term study specifically investigating children's use of a terminology associated with the forest garden may answer this question.

Although the pedagogues repeatedly talked to the children about humans' dependence on other organisms, such as pollinating insects for fruit production in the forest garden (utilitarian values), they also strongly emphasized the insects' dependence on help and assistance from the children (humanistic values). During the actual physical activities undertaken by the children in the 
miniprojects, the pedagogues frequently engaged in these latter kinds of talk and actions that were aligned with humanistic values. We suggest that these actions by the pedagogues played a part in influencing the children's expressions since it was these humanistic values that the children mainly referred to. A reason why the children rarely mention the utilitarian perspective may be that this perspective often demands reasoning that is more complex and highly sequential (e.g. flower bed insects - pollination - fruit - humans, instead of just humans - flower bed - insects). There may also be emotional components involved in the children's strong emphasis on humanistic values as indicated by the children's appreciation and joy in their helping role and seemed content with how the unidirectional relationship was constituted in the situations they experienced. However, this perception of unidirectional ecological relationships, based on humanistic values, taken alone, might be considered weak as a basis for developing awareness of sustainability, since there is no evidence that "caring for individual animals translates to individual species, any more than we know that caring for an individual human leads to caring for humanity" (Vining, 2003). Although there is neither any evidence that caring for ecosystems leads to conservation behaviour (Vining and Ebreo, 2002), maybe an understanding of ecosystem services would provide a more stable basis for environmental concern.

Ecosystem services is part of the Biology curriculum in grades 4-9 in Sweden (Swedish National Agency of Education, 2011). The children in this study are younger but from a long term perspective the learning situations in the forest garden may be helpful in developing the children's understanding of human dependence on e.g. insects. Ecosystem services, however, is intended to provide understanding of ecological processes from an anthropocentric perspective and a unidirectional view of the purpose and value of non-human organisms. It is noteworthy therefore that the children in the present study, conveyed the opposite perspective about the relationship between themselves and the organisms, especially the insects, in the forest garden. Rather than asking what these organisms can do for me/us (utilitarian perspective), they posed the question: What can I/we do for the bugs/plants/ bees? (humanistic perspective). The curriculum covering the ages of the students in the study does not point to any specific perspectives on the relation between human and non-human organisms for use in framing teaching and learning, but implicitly the values classified as scientific and symbolic are present. It is therefore interesting that the values of nature that were most commonly expressed by the children beside scientific values were humanistic, aesthetic and naturalistic values. The values expressed by the children were more in line with the former curriculum for Biology for grades 0-9 in Sweden (Swedish National Agency of Education, 2000). This former curriculum, besides describing and explaining nature from a scientific perspective, also sought to "consolidate the fascination and joy of discovery and Man's wonder and curiosity in all that is living." (Swedish National Agency of Education, 2000, p. 44), relating to aesthetic and naturalistic values which are represented with richness in the data in this study. Further the former curriculum stated that "The subject also aims at making knowledge and experiences usable to promote concern and respect for nature and one's fellow men." (Swedish National Agency of Education, 2000, p. 44), clearly expressing humanistic values.

Fägerstam and Blom (2013) concluded that authenticity, interaction and positive emotions are important aspects in outdoor learning in biology for high school students and is of importance for long term knowledge retention. When for instance talking about the activities in the forest garden, the children often referred to the physical work and its direct and immediate authentic purpose. Expressing positive emotions the children explained how they influenced and helped animals and 
plants through their work in the mini-projects. In line with the conclusions of Fägerstam and Blom perhaps a more direct physical activity, for example in which the children could work as pollinators with small paint brushes, would make it easier for them to talk about and develop concepts of insects' roles in the production of fruits and berries? Could this give them more concrete and tangible experience of the benefit they derive from and their dependence on the ecosystem services provided by pollinators? Further research is needed into the crucial question of how practical activities that encourage discussion about humans' dependence on other organisms affects children's understanding of human dependence on the ecosystems. The role pedagogues play in the development of values among the children is especially important for this understanding.

\section{Conclusions}

We suggest that the joyful experiences (aesthetic values), the appreciation of activities in the urban forest jungle (naturalistic and aesthetic values) and the joy in helping and caring for the insects and plants (humanistic values) are important reason for establishing urban forest gardens. These experiences can foster children's collaborative and creative activities such as the mini-projects described in the present study. At the same time, these experiences represent the development of values other than those stated in the current Swedish Biology curriculum (Swedish National Agency of Education, 2011) but which are in correspondence with the former curriculum (Swedish National Agency of Education, 2000). Whether present in the curriculum or not, an environment that enhances the expression of aesthetic, humanistic and naturalistic values is fundamental for children's development (Kellert, 2002; Faber Taylor and Kuo, 2006). The forest garden, at least for children of this age, is promising as environment for the development of these values, as well as of scientific and possibly also other values.

Future research should investigate whether children's experiences in forest gardens differ from children's experiences in school gardening (Blair, 2009), forest schools (O'Brien and Murray, 2007) or other similar activities. Will participation in forest garden activities contribute to creating long-lasting ties to other organisms and prepare the children for understanding of their dependence on nonhuman organisms? Comparative studies of school gardening, community gardening and forest gardening would be helpful tools when planning the greening of urban areas.

\section{Acknowledgements}

We are grateful to Dr. Robert Lecusay, Jönköping, Sweden, for critically reading the manuscript.

\section{References}

Basile, C. G., 2000. Environmental learning as a catalyst for transfer of learning in young children. Journal of Environmental Education, 32, 21-27.

Blair, D., 2009. The child in the garden: An evaluative review of the benefits of school gardening. Journal of Environmental Education, 40, 15-38

Chawla, L., 1999. Life paths into effective environmental action. Journal of Environmental Education 1, 15-26. 
Chawla, L., 2009. Growing up green: Becoming an agent of care for the natural world. Journal of Developmental Processes, 41, 6-23.

Crawford, M., 2010. Creating a forest garden: Working with nature to grow edible crops. Totnes, UK: Green Books.

Davis, B., Rea, T., Waite, S., 2006. The special nature of the outdoors: Its contribution to the education of children aged 3-11. Australian Journal of Outdoor Education, 10, 3-12.

Delors, J., 1996. Learning: The treasure within. UNESCO report for Education for the $21^{\text {st }}$ Century. London, UK: UNESCO Publications, HMSO.

Faber Taylor, A., Kuo, F.E., Sullivan, W.C., 1998. Growing up in the inner city: green places and spaces to grow. Environment and Behavior, 30, 3-27.

Faber Taylor, A., Kuo, F.E., 2006. Is contact with nature important for healthy child development? State of the evidence. In: Spencer, C., Blades, M. (Eds.), Children and Their Environments. Cambridge, UK: Cambridge University Press, pp. 124-140.

Friends of the forest garden (n.d). Retrieved January 16nd, 2015 from http://skogstradgardensvanner.se/

Fägerstam, E., Blom, J., 2013. Learning biology and mathematics outdoors: effects and attitudes in a Swedish high school context, Journal of Adventure Education and Outdoor Learning, 13:1, 56-75, DOI: 10.1080/14729679.2011.647432

Gullone, E., 2000. The biophilia hypothesis and life in the 21st century: Increasing mental health or increasing pathology? Journal of Happiness Studies, 1, 293-321.

Jacke, D., Toensmeier, E., 2005. Edible forest gardens: Ecological vision and theory for temperate climate permaculture. Vol. II. White River Junction, VT: Chelsea Green Publishing.

Kahn, P. H., 1997. Developmental psychology and the biophilia hypothesis: Children's affiliation with nature. Developmental review, 17, 1-61.

Kahn, P. H., 2003. The development of environmental moral identity. In: Clayton, S., Opotow, S. (Eds.) Identity and the Natural Environment. The Psychological Significance of Nature. Cambridge, MA: MIT Press, pp. 113-134.

Kellert, S. R., 1997. Kinship to mastery: Biophilia in human evolution and development. Washington, DC: Island Press.

Kellert, S.R., 2002. Experiencing nature: affective, cognitive and evaluative development in children. In: Kahn, P.H., Kellert, S.R. (Eds.), Children and Nature: Psychological, Sociocultural and Evolutionary Investigations. Cambridge, MA: The MIT Press, pp. 117-151.

Kellert, S.R., 2009. Biodiversity, quality of life, and evolutionary psychology. In: Sala, O. E., Meyerson, L. A., Parmesan, C. (Eds.), Biodiversity change and human health. From ecosystem services to spread of disease. Scientific Committee on Problems of the Environment (SCOPE) Ser. 69. Washington, DC: Island Press, pp. 99-127. 
Maller, C. J., 2009. Promoting children's mental, emotional and social health through contact with nature: a model. Health Education, 109, 522-543.

Kitzinger, J., Barbour, R.S., 1999. Introduction: The Challenge and Promise of Focus Groups. In: Barbour, R., Kitzinger, J. (Eds.), Developing Focus Group Research : Politics, Theory and Practice. London: SAGE, pp. 1-20.

Laaksoharju,T., Rappe, E., 2010. Children's relationships to plants among primary school children in Finland. Comparison by location and gender. HortTechnology, 20, 689-695.

Louv, R., 2008. Last child in the woods: Saving our children from nature-deficit disorder. 2nd ed, Chapel Hill, NC: Algonquin Books.

Malone, K., 2007. The bubble-wrap generation: Children growing up in walled gardens.

Environmental Education Research, 13, 513-527.

Millennium Ecosystem Assessment, 2005. Ecosystems and Human Well-being: Synthesis. Washington DC, USA: Island Press.

O'Brien, L., Murray, R., 2007. Forest School and its impacts on young children: Case studies in Britain. Urban Forestry \& Urban Greening 6, 249-265.

Patton, M.Q., 2002. Qualitative research and evaluation methods, $3^{\text {rd }}$ ed. Thousand Oaks, CA: Sage Publications.

Richardson, M., Hallam, J., Lumber, R., 2015. One thousand good things in nature: Aspects of nearby nature associated with improved connection to nature. Environmental values, 24, 603-619

Salonen, T. (2014) Sysselsättning och försörjningsvillkor i Lindängens hyresrätt - en sociodynamisk analys [Employment and conditions for livelihood a sociodynamic analysis]. Delrapport i Milprojektet Fakulteten hälsa och samhälle, Malmö University. Retrieved December 152015 fromhttps://dspace.mah.se/bitstream/handle/2043/18348/TSMilrapportAug14.pdf?sequence=3\&isA $\underline{\text { llowed }=y}$

Sandell, K., Öhman, J., 2010. Educational potentials of encounters with nature - reflections from a Swedish outdoor perspective. Environmental Education Research, 16, 95-114.

Sebba, R., 1991. The landscapes of childhood: The reflections of childhood's environment in adult memories and in children's attitudes. Environment and Behavior, 23, 395-422.

Sobel, D., 2008. Childhood and nature: design principles for educators. York, ME: Stenhouse Publishers.

Shepard, P., 1996. Traces of an omnivore. Washington, D.C.: Island Press.

Stough, L.M., 2001. Using stimulated recall in classrooms observation and professional development. Paper presented at the Annual Meeting of the American Educational Research Association. Arpil, Seattle, WASwedish National Agency of Education, 2011. Läroplan för grundskolan, förskoleklassen och fritidshemmet. Kommentarsmaterial till kursplanen i Biologi. Retrieved March 222015 from http://www.skolverket.se/publikationer?id=2609 
831 Swedish National Agency of Education, 2011. Läroplan för grundskolan, förskoleklassen och

832 fritidshemmet. Kommentarsmaterial till kursplanen i Biologi. Retrieved March 222015 from

833 http://www.skolverket.se/publikationer?id=2609

834 Swedish National Agency of Education, 2000. Syllabuses for the compulsory school. Västerås:

835 Skolverket and Fritzes.

836 Vining, J., 2003. The connection to other animals and caring for nature. Human Ecology Review, 10,

837 87-99.

838 Vining, J., Ebreo, A., 2002. Emerging theoretical and methodological perspectives on conservation

839 behavior. In: Bechtel, R.B., Churchman, A. (eds.), The New Handbook of Environmental Psychology,

840 541-558. New York, NY: John Wiley, pp. 541-558.

841 Waite, S., Bølling, M., Bentsen, P., 2015. Comparing apples and pears?: a conceptual framework for

842 understanding forms of outdoor learning through comparison of English Forest Schools and Danish

843 udeskole. Environmental Education Research, DOI: 10.1080/13504622.2015.1075193

844 Wibeck, V., 2010. Fokusgrupper: Om fokuserade gruppintervjuer som undersökningsmetod. Lund:

845 Studentlitteratur.

846 Whitefield, P., 2002. How to Make a Forest Garden. Permanent Publications, East Meon, England.

847 Wilson, E. O., 1984. Biophilia. Cambridge, MA: Harvard University Press. 